STATE OF ALASKA

DEPARTMENT OF NATURAL RESOURCES

Alaska Geologic Materials Center Data Report No. 416

\title{
No. 416
}

Baseline Resolution, Inc., 2013, Total organic carbon and rock-eval pyrolysis of core and core chips from the OCS Y-O280 ANTARES \# 1, BADAMI \# 1, FIORD \#1, and W KUPARUK ST \#3-11-11 wells

Spreadsheet available for download

Received November 2012

All data reports may be downloaded free of charge from the DGGS website. 